\title{
Conservation status of the Sichuan Hill-partridge Arborophila rufipectus in China
}

\author{
DAI BO, SIMON D. DOWELL, RODNEY P. MARTINS and \\ ROBERT S. R. WILLIAMS
}

\section{Summary}

The critically endangered Sichuan Hill-partridge Arborophila rufipectus occupies a restricted range in south-central China. Field surveys within this range were undertaken using line transects in 1996 and 1997. Calling males were recorded from nine subtropical forest tracts within an area totalling $1,793 \mathrm{~km}^{2}$ and consisting of primary, natural secondary and replanted broadleaf forest between 1,100 and 2,235 m elevation. The only sightings obtained were in primary forest. The mean density of calling males estimated from data collected during transect surveys was $0.48 \pm 0.06$ and $0.24 \pm 0.16$ calling birds $\mathrm{km}^{-2}$ in 1996 and 1997 respectively. There was no difference in density estimates for calling males between primary forest and secondary/replanted broadleaf forest. The principal threat to the continued survival of the species is clear-felling of primary forest, but clear-felled areas are often replanted with native broadleaf trees and records of Sichuan Hill-partridge calls in such plantations offers hope for its future survival. Forest management should be modified to make forestry practices more sympathetic to the conservation of the Sichuan Hill-partridge.

\section{Introduction}

The Sichuan Hill-partridge Arborophila rufipectus is critically endangered and regarded as one of the world's most threatened Galliformes because of its restricted range and the disappearance of its forest habitat (McGowan et al. 1995). The species occurs in subtropical deciduous/evergreen broadleaf forest between 1,100 and $2,250 \mathrm{~m}$ in southern Sichuan Province, China. This forest type is important for four other restricted range bird species and is within the Chinese Subtropical Forests Endemic Bird Area (EBA) as identified by BirdLife International (Stattersfield et al. 1997).

The Sichuan Hill-partridge was first described by Boulton (1932) who collected the type-specimen, a male, from Daqiao, Ganluo County, southern Sichuan. In the 1960 s further specimens were collected and observations made in the Wuzhishan range, Pingshan County at 1,300-1,800 $\mathrm{m}$ elevation (Li et al. 1974). During a visit to Huanglianshan, Mabian County in 1986 up to 11 calling males were recorded per day from subtropical forest at an altitude of 1,200-1,500 $\mathrm{m}$ (King and $\mathrm{Li} \mathrm{1988).} \mathrm{These} \mathrm{authors} \mathrm{were} \mathrm{alarmed} \mathrm{at} \mathrm{the} \mathrm{speed} \mathrm{of} \mathrm{primary} \mathrm{forest} \mathrm{destruc-}$ tion at this site, and from this they predicted the extinction of the Sichuan Hill- 
partridge within 40 years (King and $\mathrm{Li}$ 1988). Further surveys in Huanglianshan took place between 1988 and 1992 ( $\mathrm{Li}$ and Zhang 1992, Xu et al. 1994). Three nests, each containing 3-7 eggs, were found in recently felled areas ( $\mathrm{Li}$ and Zhang 1992) and calling males were recorded from secondary broadleaf forest, though the population density appeared to be nearly four times greater in the remaining primary forest ( $\mathrm{Xu}$ et al. 1994).

Short visits made to southern Sichuan by McGowan (1993) and Dowell (1995) on behalf of the World Pheasant Association demonstrated that considerable areas of apparently suitable habitat in the region had not been surveyed for Sichuan Hill-partridge. These included neighbouring areas of Yunnan Province from where the species is not recorded in the literature but where apparently suitable habitat exists.

In order to develop an effective strategy for its conservation, surveys of the Sichuan Hill-partridge were carried out in 1996 and 1997. The objectives were to: (i) establish the current distribution and population density of the Sichuan Hill-partridge; (ii) investigate its response to habitat change caused by forestry operations; (iii) identify the main threats to its future survival.

\section{Methods}

\section{Study Area}

During 1996 the survey area was centred around the Counties of Mabian, Leibo, E'Bian and Pingshan in southern Sichuan (Figure 1). In 1997, the neighbouring counties of Yongshan, Daguan and Suijiang in northern Yunnan were also visited. Most of this area is mountainous, rising to over $4,000 \mathrm{~m}$ in the west, with deep valleys and steep slopes. The climate is seasonal, key features being warm, wet summers and cold winters. In the valleys mean annual precipitation falls within the range $1,200-1,400 \mathrm{~mm}$ and recorded temperature variation ranges from $-4{ }^{\circ} \mathrm{C}$ to $34{ }^{\circ} \mathrm{C}$. In general, higher altitudes experience a colder and wetter climate but there is considerable variation in local climatic conditions related to altitude, aspect and topography.

The area was once heavily forested (Yang and Li 1992) but deforestation for timber and to provide land for agriculture has reduced and fragmented the original vegetation cover. There are now no extensive forests below 1,000 $\mathrm{m}$ (King and $\mathrm{Li}$ 1988). From 1,000 to $2,000-2,300 \mathrm{~m}$ the remaining forest is subtropical broadleaf with a mixture of deciduous and evergreen species and bamboo understorey. Above 2,000-2,350 $\mathrm{m}$ there is zonation through mixed to coniferous forest up to a treeline between 3,000 and $3,500 \mathrm{~m}$. The Sichuan Hill-partridge has not been recorded above $2,250 \mathrm{~m}$, despite searches at higher altitudes (e.g. King and Li 1988) so fieldwork during this study concentrated on subtropical broadleaf forest up to $2,250 \mathrm{~m}$.

During fieldwork, a total of 10 broadleaf forest tracts was visited; seven in Sichuan and three in Yunnan (details in Table 1). Of these, five forest tracts were visited in both years of the survey, two in 1996 only and three others in 1997 only. Maps and data on the size of forest blocks were provided by the Sichuan Forestry Department. 


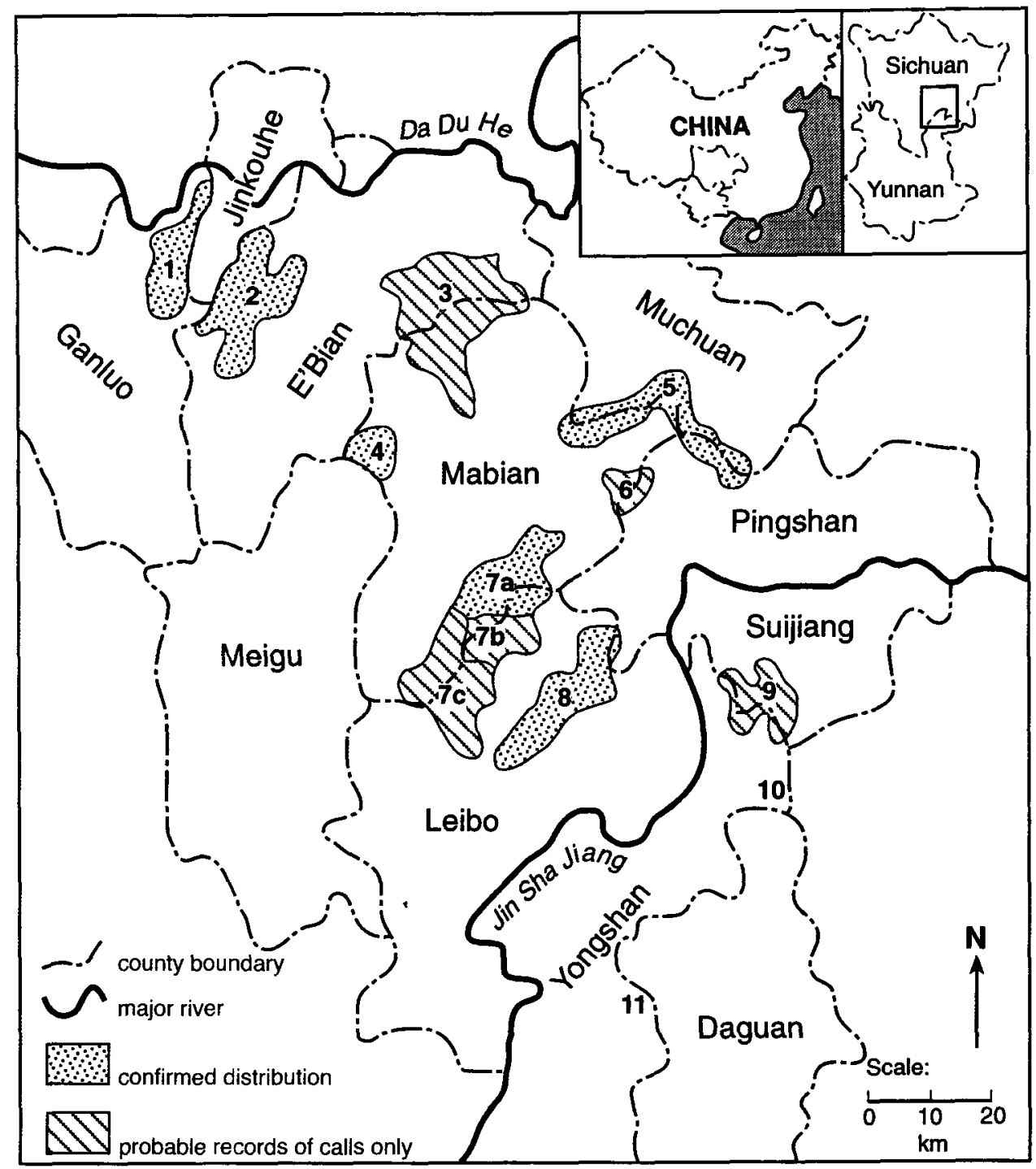

Figure 1. Distribution of the Sichuan Hill-partridge based on Boulton 1932, Li et al. 1974, King and Li 1988, Li and Zhang 1992, Xu et al. 1994 and this study. Refer to Table 1 for the names of numbered sites.

\section{Call Counts}

The Sichuan Hill-partridge is elusive so a census of the species must rely on detecting calls. Two types of far-carrying call are given by the male during the breeding season (March to June), an ascending call and a more complex whistle (Xu et al. 1994). Calls are most frequently uttered during the first four hours after dawn and from about 16 hoo until just before dusk, although they can sometimes be heard at other times of the day. There are no records of calls at night. Little 
Table 1. Forest tracts surveyed for Sichuan Hill-partridge. All except 1 (the type locality) were visited during fieldwork in 1996 and/or 1997. Numbered sites relate to those shown on Figure 1.

\begin{tabular}{|c|c|c|c|c|}
\hline $\begin{array}{l}\text { Forest } \\
\text { tract no. }\end{array}$ & Forest tract name & Province and county & $\begin{array}{l}\text { Latitude and } \\
\text { longitude of } \\
\text { central point }{ }^{2}\end{array}$ & $\begin{array}{l}\text { Forest } \\
\text { area }^{2} \\
\left(\mathrm{~km}^{2}\right)\end{array}$ \\
\hline 1 & Daqiao & Sichuan, Ganluo & $29^{\circ} 11^{\prime} \mathrm{N}, 102^{\circ} 57^{\prime} \mathrm{E}$ & 152 \\
\hline 2 & Heizhugou-Laoyingzui & Sichuan, E'bian & $29^{\circ} 3^{\prime} \mathrm{N}, 102^{\circ} 56^{\prime} \mathrm{E}$ & 202 \\
\hline 3 & Dazhuba-Pingdeng & Sichuan, E'bian/Mabian & $29^{\circ} 3^{\prime} \mathrm{N}, 103^{\circ} 24^{\prime} \mathrm{E}$ & 304 \\
\hline 4 & Leikou & Sichuan, E'bian/Mabian & $28^{\circ} 57^{\prime} \mathrm{N}, 103^{\circ} 15^{\prime} \mathrm{E}$ & 84 \\
\hline 5 & $\begin{array}{l}\text { Huanglianshan- } \\
\text { Wuzhishan }\end{array}$ & $\begin{array}{l}\text { Sichuan, Mabian/ } \\
\text { Muchuan }\end{array}$ & $28^{\circ} 51^{\prime} \mathrm{N}, 103^{\circ} 4 \mathrm{o}^{\prime} \mathrm{E}$ & 135 \\
\hline 6 & Tianba & Sichuan, Mabian/Pingshan & $28^{\circ} 47^{\prime} \mathrm{N}, 103^{\circ} 44^{\prime} \mathrm{E}$ & 27 \\
\hline $7 a$ & Yangsiba & Sichuan, Mabian/Leibo & $28^{\circ} 38^{\prime} \mathrm{N}, 103^{\circ} 37^{\prime} \mathrm{E}$ & 507 \\
\hline $7^{b}$ & Guandoushan & Sichuan, Leibo & $28^{\circ} 34^{\prime} \mathrm{N}, 103^{\circ} 36^{\prime} \mathrm{E}$ & \\
\hline $7 \mathrm{c}$ & Ledugou-Erbagou & Sichuan, Leibo & $28^{\circ} 27^{\prime} \mathrm{N}, 103^{\circ} 25^{\prime} \mathrm{E}$ & \\
\hline 8 & $\begin{array}{l}\text { South bank of Xining } \\
\text { River }\end{array}$ & Sichuan, Leibo & $28^{\circ} 22^{\prime} \mathrm{N}, 103^{\circ} 36^{\prime} \mathrm{E}$ & 270 \\
\hline 9 & Ershisigeng & $\begin{array}{l}\text { Yunnan, Suijiang/ } \\
\text { Yongshan }\end{array}$ & $28^{\circ} 27^{\prime} \mathrm{N}, 103^{\circ} 56^{\prime} \mathrm{E}$ & 112 \\
\hline 10 & Daxuecao & $\begin{array}{l}\text { Yunnan, Yongshan/ } \\
\text { Daguan }\end{array}$ & $28^{\circ} 15^{\prime} \mathrm{N}, 103^{\circ} 59^{\prime} \mathrm{E}$ & 91 \\
\hline 11 & Haozhiba & $\begin{array}{l}\text { Yunnan, Yongshan/ } \\
\text { Daguan }\end{array}$ & $28^{\circ} 3^{\prime} \mathrm{N}, 103^{\circ} 38^{\prime} \mathrm{E}$ & 16 \\
\hline
\end{tabular}

${ }^{1}$ Latitudes and longitudes obtained from Microsoft Encarta 97 World Atlas.

${ }^{2}$ Forest areas calculated from 1996 data.

is known about the function of these calls although they are assumed to be associated with territory establishment and maintenance and/or mate attraction ( $\mathrm{Xu}$ et al. 1994).

Although Sichuan Hill-partridge calls are fairly distinctive if heard clearly, the Spotted Laughing-thrush Garrulax ocellatus, which occurs in some of the same forest areas, sometimes gives similar calls which can cause confusion. As a result of this, some caution has been applied to the results of our survey.

\section{Line Transects}

Up to ten 1,000-m length transects, at least $1,000 \mathrm{~m}$ apart, were selected in each forest tract. Given the nature of the terrain, transects were generally sited along pathways, forest roads or ridge lines. Transects were undertaken within primary, natural secondary, and broadleaf and coniferous forest and plantations. Each transect was walked at least once in any one year while some were repeated in both. Significantly less time was available for transect work in 1997 when field surveys of other bird species were also carried out. All transect data were collected between o5h3o and ogh3o or between 16 hoo and 20 hoo in April, May and June. None were undertaken during periods of high winds and/or heavy rain.

One or two observers walked each transect, pausing for three minutes after every $50 \mathrm{~m}$ (approximately 100 paces) to imitate the ascending whistle call 15 times and listen for calls. Each transect took 1.5 hours to complete. When a Sichuan Hill-partridge call was detected, its distance from the transect line was estimated to the nearest $100 \mathrm{~m}$ and noted along with the time, call type 
(ascending or complex whistle), frequency of call and forest type from which the call was thought to emanate.

Data from line transects were used to calculate density estimates of calling male Sichuan Hill-partridges using the linear model of the two-belt transect method (Bibby et al. 1992). The relevant equation is given below:

$$
\mathrm{D}=1 \mathrm{ONK} / \mathrm{L}
$$

where

$$
K=\left(1-V\left(1-N_{1} / N\right)\right) / W
$$

where $\mathrm{D}$ is density of calling males per hectare; $\mathrm{N}$ is the total number of birds recorded on all transects; $N_{1}$ is the number recorded within the inner belt; $W$ is the belt width (taken as $300 \mathrm{~m}$ ); $\mathrm{L}$ is the total length of transect in kilometres; and $\mathrm{K}$ is a constant calculated using the formula shown.

Individuals observed or heard during fieldwork outside the transect periods were also recorded. For each record, date, time of day, altitude, forest type and type of record (sighting or vocalization) were noted. All records were combined to give a summary of each season's fieldwork.

\section{Threats}

Potential threats to the Sichuan Hill-partridge were identified during the survey by qualitative observations and through interviews with local Forestry Officials. Further information and literature were provided by the Sichuan Forestry Department.

\section{Results}

\section{Numbers and distribution}

Totals of 72 and 37 Sichuan Hill-partridges were recorded in 1996 and 1997, respectively (Table 2 ). Most records were of calling males. The only sightings obtained were in primary forest at Yangsiba and south of the Xining River. The largest numbers were recorded from undisturbed primary forest, although this reflects the fact that more fieldwork was carried out in that habitat than in other forest types. These records together with those available in the literature have been combined to produce the known distribution map of the species (Figure 1). The current area of forest (primary, secondary and replanted) in the confirmed forest tracts, i.e. where sightings have been obtained and/or birds captured, is $1,350 \mathrm{~km}^{2}$, whilst the total area of forest in all forest tracts, including those where the species has only been heard, is $1,793 \mathrm{~km}^{2}$ (Forest area data provided by the Sichuan Forestry Department). The distribution of Sichuan Hill-partridge records reflects the highly fragmented distribution of remaining broadleaf forest patches in the region.

\section{Population density}

The density of calling males, estimated from all transect surveys, was $<0.5$ males $/ \mathrm{km}^{2}$ in both years, although more intensive surveys in 1996 recorded 
Table 2. Summary of all Sichuan Hill-partridge records (including calls heard that were presumed to be this species) during fieldwork in 1996 and 1997. Forest tract numbers are those shown in Figure 1.

\begin{tabular}{|c|c|c|c|c|c|}
\hline $\begin{array}{l}\text { Forest } \\
\text { tract no. }\end{array}$ & Forest name & No. recorded 1996 & No. recorded 1997 & $\begin{array}{l}\text { Altitudinal } \\
\text { range }(\mathrm{m})\end{array}$ & $\begin{array}{l}\text { Forest } \\
\text { type (no. } \\
\text { recorded) }\end{array}$ \\
\hline 2 & $\begin{array}{l}\text { Heizhugou- } \\
\text { Laoyingzui }\end{array}$ & $\begin{array}{l}3 \text { heard ( } 4 \text { trapped } \\
\text { in 1995/96, } \\
\text { identified by } \\
\text { Sichuan University) }\end{array}$ & 3 heard & $1,465-2,030$ & $\begin{array}{l}\mathrm{UP}(3), \\
\mathrm{DP}(1) \\
\mathrm{NS}(2)\end{array}$ \\
\hline 3 & Dazhuba-Pingdeng & 7 heard & 3 heard & $1,785-2,235$ & $\begin{array}{l}\mathrm{UP}(7), \\
\mathrm{DP}(1), \\
\mathrm{NS}(2)\end{array}$ \\
\hline 4 & Leikou & $\begin{array}{l}\text { None recorded ( } 1 \\
\text { captured in 1995) }\end{array}$ & Not visited & - & - \\
\hline 5 & $\begin{array}{l}\text { Huanglianshan- } \\
\text { Wuzhishan }\end{array}$ & $10^{7}$ seen 7 heard & 1 heard & $1,400-1,685$ & $\begin{array}{l}\mathrm{DP}(3) \\
\mathrm{NS}(6)\end{array}$ \\
\hline 6 & Tianba & 11 heard & Not visited & $1,340-1,730$ & $\mathrm{DP}(11)$ \\
\hline $7 \mathrm{a}$ & Yangsiba & 15 heard & $\begin{array}{l}20^{\prime} 19 \text { seen } 8 \\
\text { others heard }\end{array}$ & $1,100-1,690$ & $\begin{array}{l}\mathrm{UP}(23) \\
\mathrm{DP}(3)\end{array}$ \\
\hline $7 \mathrm{~b}$ & Guandoushan & 2 heard & I heard & $1,620-1,700$ & $\begin{array}{l}\mathrm{UP}(1) \\
\mathrm{DP}(2)\end{array}$ \\
\hline $7 \mathrm{C}$ & Ledugou-Erbagou & 4 heard & 5 heard & $1,410-1,950$ & $\begin{array}{l}\mathrm{UP}(2), \\
\mathrm{DP}(4), \\
\mathrm{RB}(3)\end{array}$ \\
\hline 8 & $\begin{array}{l}\text { South bank of } \\
\text { Xining River }\end{array}$ & 21 heard $1 \sigma^{7}$ seen & 9 heard & $1,350-2,110$ & $\begin{array}{l}\mathrm{UP}(16), \\
\mathrm{DP}(8) \\
\mathrm{NS}(1) \\
\mathrm{RB}(6)\end{array}$ \\
\hline 9 & Ershisigeng & Not visited & 4 heard & $1,550-1,600$ & $\mathrm{NS}(4)$ \\
\hline 10 & Daxuecao & Not visited & None recorded & - & 一 \\
\hline 11 & Haozhiba & Not visited & None recorded & - & 一 \\
\hline Total & All sites & 72 individuals & 37 individuals & $1,100-2,235$ & $\begin{array}{l}\text { UP(52), } \\
\text { DP(33), } \\
\text { NS(15), } \\
\text { RB(9) }\end{array}$ \\
\hline
\end{tabular}

${ }^{1}$ Forest types: UP, Undisturbed primary subtropical broadleaf; DP, Disturbed primary subtropical broadleaf (selectively logged); NS, Natural secondary broadleaf; RB, Replanted broadleaf.

higher densities than those in 1997 (Table 3). Density estimates from primary forest were not significantly higher than those in secondary and replanted broadleaf forest in either year $\left(1996, \chi^{2}=0.08, d f=1, P>0.75 ; 1997, \chi^{2}=1.83, d f=1, P>\right.$ o.10; $\chi^{2}$ tests were calculated using density of calling males per $100 \mathrm{~km}^{2}$; see Table 3). The species was not recorded from coniferous plantations. It should be emphasised that all records of Sichuan Hill-partridge on transect surveys were of calling birds only and should therefore be treated with some caution in the light of possible confusion with the calls of Spotted Laughing-thrush.

\section{Threats}

The following potential threats were identified.

Deforestation The main threat is habitat destruction by clear-felling of primary forest for timber. There are currently over 20 state-owned and collective forestry 
Table 3. Density estimates for calling male Sichuan Hill-partridges calculated from line transect survey data using the linear model for the two-belt method (inner belt, $300 \mathrm{~m}$ ).

\begin{tabular}{|c|c|c|c|c|}
\hline \multirow[t]{2}{*}{ Forest type } & \multicolumn{2}{|l|}{1996} & \multicolumn{2}{|l|}{1997} \\
\hline & No transects & $\begin{array}{l}\text { Mean density of } \\
\text { calling males per } \\
\mathrm{km}^{2} \pm \text { standard } \\
\text { error }\end{array}$ & No. transects & $\begin{array}{l}\text { Mean density of } \\
\text { calling males per } \\
\mathrm{km}^{2} \pm \text { standard } \\
\text { error }\end{array}$ \\
\hline Primary & 63 & $0.57 \pm 0.09$ & 12 & $0.30 \pm 0.16$ \\
\hline $\begin{array}{l}\text { Natural and } \\
\text { replanted } \\
\text { secondary }\end{array}$ & 31 & $0.54 \pm 0.03$ & 10 & $0.17 \pm 0.14$ \\
\hline $\begin{array}{l}\text { Coniferous } \\
\text { plantation }\end{array}$ & 11 & 0 & - & - \\
\hline $\begin{array}{l}\text { Mean density (all } \\
\text { sites) }\end{array}$ & 108 & $0.4^{8} \pm 0.06$ & 22 & $0.24 \pm 0.16$ \\
\hline
\end{tabular}

enterprises logging the area (Wang 1994) and almost all of the remaining primary broadleaf forest is scheduled for logging over the next 20-25 years. Much of the clear-felled land is replanted with a small selection of quick-growing native broadleaf species obtained from the original forest and grown in nurseries at the local Forestry Farm Headquarters. One to two year-old saplings are planted and kept free of competing "weeds" (including bamboo) for three to five years, after which the plantations are unmanaged (Cao 1989). After 15-20 years these plantations resemble natural secondary forest although tree diversity is lower. Up to $40 \%$ of the replanted forest is currently intended to be harvested after approximately 50 years (Wang 1994). The remainder will be left to protect mountain sides from excess run-off and associated erosion that could lead to flooding downstream.

Poaching Hunting and trapping of gamebirds is traditional, especially amongst the indigenous $\mathrm{Yi}$ people. It is illegal but difficult to control in the mountainous terrain. Most hunters seek larger quarry such as Temminck's Tragopan Tragopan temminckii, but Sichuan Hill-partridges are sometimes trapped as well. Despite this there is currently no evidence that poaching is having a major impact on Sichuan Hill-partridge populations.

Bamboo shoot collection Disturbance from bamboo shoot collectors occurs seasonally in spring and early autumn when several hundred people may roam the forest in search of young bamboo shoots. This could cause disturbance to breeding birds.

Agricultural activity Grazing of the understorey herbs and shoots by local livestock damages the leaf litter where the Sichuan Hill-partridge feeds and could cause disturbance and trampling of nests. In some places local farmers are clearing the forest for agriculture.

Construction Localized road construction is making more forest accessible to logging operations and hunting, whilst mining activity causes disturbance and forest destruction. 


\section{Discussion}

Our survey results would appear to justify the concern expressed over the future survival prospects of the Sichuan Hill-partridge (King and Li 1988, Xu et al. 1994, McGowan et al. 1995). The species occurs at low densities in a highly fragmented habitat. It is threatened by deforestation, poaching, agricultural activities and disturbance from bamboo shoot collectors. At Huanglianshan, records from visiting ornithologists over the past 11 years indicate a serious decline from counts of up to 11 calling males per day in the late 1980s (King and Li 1988) to just a single record during six days of field work in 1997 (this study). The reason for the decline in numbers in this forest tract would seem to be the replacement of the primary forest with non-native conifer plantations which are unsuitable for the Sichuan Hill-partridge.

More encouragingly, Sichuan Hill-partridges were heard calling from secondary broadleaf forest, resulting from both natural regeneration and the more species-poor forest created by broadleaf replanting, although none of these records were backed up by sightings. Population density estimates from transect data in primary forest were not significantly different from those in secondary/replanted broadleaf forest. There may be a relationship between the recolonization of secondary forest and the proximity to primary forest source areas ( Xu et al. 1994). The species was also heard calling for the first time from a site in Yunnan, although because of possible confusion with Spotted Laughing-thrush we propose that a further visit be made to the forest tract involved to seek confirmation through sightings.

\section{Priorities for future conservation action}

Remaining areas of primary forest are likely to be important, both for Sichuan Hill-partridge and for other bird species, and future management proposals should include measures to protect a network of substantial primary forest tracts as an urgent priority. This could be achieved by expanding on current protected area policies in the region. We propose a network of four protected areas across the range linked by corridors of primary forest on ridges and steep slopes. These should aim to conserve primary forest areas in all parts of the known range of the Sichuan Hill-partridge. The speed with which primary forest is being logged in the region necessitates rapid but effective action on the establishment of protected areas. There is a greater chance of achieving protected area status for primary forest if proposals build on existing forest protection designations rather than proposing new ones. In existing protected areas, investment in the infrastructure required to achieve protection has already been made and the support of local people for the conservation effort has been secured. Extensions to the protected status or the area covered can therefore be made relatively quickly. Within the study area there is one National Nature Reserve and two proposed Forest Parks (a tourism designation affording some protection to the native forest). The National Nature Reserve is Dafending Giant Panda Reserve in the south-west of Mabian County. At present, most of this reserve is coniferous forest above $2,250 \mathrm{~m}$, beyond the upper altitudinal limit of Sichuan Hill-partridge distribution. Approximately $30 \mathrm{~km}^{2}$ of primary subtropical forest remains south of 
the reserve boundary, extending to Ledugou in forest tract $7 \mathrm{C}$ (Figure 1), though logging operations are encroaching. We propose an extension of the Dafending Reserve to cover this area and protect it from further exploitation.

The proposed Forest Parks are at Heizhugou-Laoyingzui in E'Bian County in the north of the study area and Ershisigeng in Suijiang County in the south where presence of Sichuan Hill-partridge awaits confirmation (forest tracts 2 and 9, Figure 1). There are plans to develop tourism in these areas with visitor facilities at main access points, although these await official approval. The main attraction will be the existence of forest, so ensuring the protection of the forest cover. Core areas should be set aside as nature reserves and tourists excluded to protect wildlife.

In addition to modifications of existing protected areas, we propose the establishment of one new Nature Reserve, covering at least $25 \mathrm{~km}^{2}$ in the Yangsiba area on the Mabian/Leibo border, centred around the Banlixi Ridge (forest tract $7 \mathrm{a}$, Figure 1). This area contains the largest block of undisturbed, intact primary forest within the known range of the Sichuan Hill-partridge and it is where the highest numbers of Sichuan Hill-partridge were recorded from primary forest during the survey (Table 2). The area does not currently enjoy any protection and encroachment by logging activities is taking place at an alarming pace. It will be much more difficult to establish a protected area here where resources are limited and local livelihoods depend on the continuation of commercial forestry, but it should be given the highest priority on conservation grounds.

Much clear-felling in the range of the Sichuan Hill-partridge is now followed by replanting of broadleaf trees to protect soil and water resources (Cao 1989, Wang 1994). A small modification of this forestry policy to enhance its wildlife conservation function could benefit the Hill-partridge and help other forest species. Logging and replanting of broadleaf trees should follow a rotational pattern to ensure that there are blocks of mature forest available at all times. At present, strips of primary forest $50 \mathrm{~m}$ either side of ridges are sometimes left unlogged to protect watersheds (Wang 1994). The width of such areas should be extended to at least $100 \mathrm{~m}$ either side of a ridge in order to provide a more substantial habitat corridor. On the steepest and most inaccessible slopes, primary forest is difficult to harvest and therefore left alone. Such forest patches might be invaluable source areas, although few records of Sichuan Hill-partridges were from such steep areas. More primary forest patches of 25-30 ha could be provided, linked by the forested ridge corridors. These could also be used to link primary forest in the proposed Nature Reserve network. Clear-felled areas between forest patches and corridors should continue to be replanted with native broadleaf trees. Except for Huanglianshan and Tianba, where commercial forestry is economically important, replanting with conifers below $2,250 \mathrm{~m}$ should be discouraged in favour of native broadleafs.

In addition to these proposals, further research on the distribution and ecology of the Sichuan Hill-partridge is needed. Surveys of suitable forest to the north and west of the known range are necessary to establish the limits of the species's distribution. Surveys in Suijiang and neighbouring counties in northern Yunnan are required to confirm the presence of the species there and establish its population density. 


\section{Acknowledgements}

The Sichuan Hill-partridge Project has received funding from the following individuals and organizations: Mr. Abdul Jalil, British Airways Assisting Conservation, The Oriental Bird Club, Stiftung Avifauna Protecta, The World Pheasant Association and The Zoological Society for the Conservation of Species and Populations. Simon Dowell's involvement in 1997 was made possible by a research travel grant from The British Ecological Society. Rodney Martins was partially funded by the British Ornithologists' Union. Robert Williams was funded by Biosphere Consultants. The authors are grateful to the Directors of the Conservation Department in the Chinese Ministry of Forestry, Mr Wang Wei and Mr Yan Xun and to the Directors of the Wildlife Division in the Sichuan Forestry Department, Mr Hu Tie-qing and Mr Deng Xiang-sui for granting permission to undertake the work. The project's counterpart in Beijing, Mr He Fen-qi of the Institute of Zoology, Academia Sinica gave crucial assistance to the entire project. Ms Xiong Bairong, Mr Yuan Shijun and Mr Wang Ji-wei of the Sichuan Forestry Department helped to arrange visas and permits. We are grateful to all local officials, guides, forestry workers and our drivers in the study area for their kind and valuable assistance during our fieldwork, especially Tao Yingao, Wang Wende, Li Bo-liang, Li Guang-yan and Hu Ya-qiu. We would like to thank Philip McGowan and John Carroll for their comments on and help with earlier drafts of the manuscript.

\section{References}

Bibby, C. J., Burgess, N. D. and Hill, D. A. (1992) Bird census techniques. London, U.K.: Academic Press.

Boulton, R. (1932) A new species of tree partridge from Szechwan, China. Proc. Biol. Soc. Washington 45: 235-236.

Cao Zheng-qi, ed. (1989) A corpus of forestry policies and statutes (1979-1989). Chengdu, China: Sichuan People's Publishing House. (In Chinese).

Dowell, S. D. (1995) Current status and future prospects for the Sichuan hill-partridge. World Pheasant Assoc. News 49: 6-13.

King, B. and Li Gui-yuan (1988) China's most endangered galliform. Oryx 22: 216-217

Li Gui-yuan and Zhang Qing-mao (1992) The nests, eggs and calls of the Sichuan hillpartridge (Arborophila rufipectus). Acta Zool. Sinica 38: 108-109 (In Chinese).

Li Gui-yuan., Liu Liang-cai, Zhang Rui-yun. and Zhang Qing-mao. (1974) Discovery of the female of the Sichuan hill-partridge (Arborophila rufipectus). Acta Zool. Sinica 20: 421422 (In Chinese).

McGowan, P. J. K. (1993) Report on visit to China, 17th November - 3rd December 1993. Unpublished Report. Reading, U.K.: World Pheasant Association

McGowan, P. J. K., Dowell, S. D., Aebischer, N. J. and Carroll, J. P. (1995) Partridges, quails, francolins, guineafowl and snowcocks: an action plan for their conservation. Gland, Switzerland: IUCN.

Stattersfield, A. J., Crosby, M. J., Long, A. J. and Wege, D. C. (1997) Endemic bird areas of the world: priorities for biodiversity conservation. Cambridge, U.K.: BirdLife International.

Wang Ji-gui, ed. (1994) History of Sichuan forestry. Chengdu, China: Sichuan Sciences and Technology Publishing House (In Chinese).

Xu Zhao-hui., Mei Wen-zheng, Zhang Gang, Chen Xin-hua and Zeng Zhao-qun (1994) Observations on the wintering habits of the Sichuan hill-partridge. Chinese J. Zool. 29: 21-23 (In Chinese with English abstract) . 
Yang Yu-po and Li Cheng-biao, eds. (1992) Forests in Sichuan. Beijing, China: China Forestry Publishing House (In Chinese).

\section{DAI BO}

Wildlife Conservation Division, Sichuan Provincial Forestry Department, No. 15, Section 1st of Renminbeilu Street, Chengdu 610082, Sichuan Province, P.R. of China

\section{SIMON D. DOWELL}

School of Biological \& Earth Sciences, Liverpool John Moores University, Byrom Street, Liverpool $L_{3} 3 A F, U . K$.

\section{RODNEY P. MARTINS}

6, Connaught Road, Norwich, Norfolk NR2 $3 B P$, U.K.

ROBERT S. R. WILLIAMS

Biosphere Consultants, 6, Waldeck Road, Norwich, Norfolk NR4 ${ }_{4} P G, U . K$. 